\title{
Work as a Perfection of the Human Person: A Philosophico- Theological Contextualization of 2 Thes. 3,10
}

\author{
Dominic Obielosi \& Stanley Mgbemena \\ http://dx.doi./org/10.4314/ujah.v18i2.6
}

\begin{abstract}
In the first creation account, Gen 1,28 God mandated man to conquer the earth and subdue. Immediately after the fall in Gen 3, God spells out work as the only way through which man would get his daily bread. It follows therefore, that work remains a conditio sine qua non for man's survival whether he is at peace with God or no. Hannah Arendt the French philosopher understands work as having a self perfective dimension. Plato in his Republic groups the organization of his political society according to the work every group does. This paper footnotes Paul's instruction to the Thessalonians to project work as part and parcel of man. It views work as that which perfects man. The researcher believes that without work, the human person can neither be perfected nor can he survive. Thus, the paper documents that work is not just a virtue for survival, it also perfects the human person in as much as it perfects nature. The researcher takes work from the backdrop of its holistic dimension as a term. Distinctions are not made as to the different types or classes of works. The common denominator is that every work perfects the human person. The researcher encourages every person to go back to his drawing board and bend down to work. He believes that God created us without us but cannot help us without us. Using exegetical lens, the paper interprets 2Thes 3,10 from the background of practical experience. It makes a call to all to struggle not just to survive or succeed but
\end{abstract}


to become significant through greater perfections realizable only through hard work.

\section{Introduction}

"Be fruitful and multiply and fill the earth and subdue it." This is God's injunction to man in Gen 1,27-28. In chapter 3 of the same book, God cursed the ground because of man after the original sin that he could only eat out of the sweat of his brow. These two accounts not only lay manifest the ambiguity of work as to whether it is a blessing or a curse, but also bears an irrefutable witness to this fact that work is a fundamental dimension of man's life on earth. A look at the different disciplines that study man namelyAnthropology, paleontology, History, sociology, psychology attest to this claim. If work then is a dimension of human existence, then the following questions flow necessarily- does man live to work or work to live? Does some form of working belong to the achievement of life or could we ideally get along without working? Any answer we give to any of these questions is no longer on the academic level, but has obvious consequences for our view of society, our ideal of education and our perception of the human person.

This paper settles for the opinion that work is not just part of and parcel of the human person. It perfects man. It means the man's life on earth. It defines the human person and distinguishes him from the rest of creatures. Other animals labour to some extent but only instinctually. Only man understands the reason for his work and so decides on what type of work and how he does it. The researcher moves from philosophical views to exegetical analysis of 2Thes 3,10 to demonstrate that work is not a curse but in the nature of man for a better man and society. 


\section{Some Historical Views on Work Ancient}

In the ancient and classical period, a negative concept of work is always prevalent. They were always hostile to manual work. This is evident from the Greek, French and Latin word for work. The Greek word for work is avscolh (aschole) which is a negation of scolh (schole) meaning leisure. Similarly the Latin term "laborare" designates work and suffering or even their word for business "negotium" which is opposite of "otium" meaning leisure. The French "inavail" which is similar to "tripallium" in Latin, which means that used in holding stubborn horse so as transport them.

The Greeks see work as suffering that should be done by slaves as opposed to the contemplative activity of the noble men, which helps them forget their incarceration in the geosphere. Thus Plato excludes machines from the government of the state. Even in his dialogue "Gorgias" he is very contemptuous to engineers and said "you can neither give your dough to his son nor marry his own daughter" Aristotle held that every work is vile in as much as it oppresses the intelligence. Cicero and Seneca extolled idleness as superior to work.

In the Ancient Near East as epitomized in the Gen 3 work is seen as punition. However, in the New Testament a new evaluation of work is given. Work is ennobled by making it a moral and soteriological criterion insofar as work frees man from sloth and prepares him for reward. Thus St Paul enjoined the Christians who do not work, to go on working than interfering with another's else. And those who do not, he said should not eat (2 Thes 3:10-13). 


\section{The Middle Ages}

UNESCO'S declaration that "everyone has right to work," would have been as unintelligible in the earlier part of the middle ages as in the ancient Greek. This is because they also evaluated work negatively, at least initially. St Thomas allowed four grounds which could make a work morally justified.

Necessary for most to maintain life

Necessary for many to avoid illness and sin

It is a form of penance

It enables us to give alms

The age of the renaissance protestant reformation criticized by the cult of the will and romanticism i.e. anthropocentric mentality, extolled work. Work is then seen as something important and fundamental in the realms of activities for man's development and his eternal salvation. It came to be regarded as a kind of predestination by Calvinism. It belonged for them to the reign of the elect or the reign of the heavens. Voltaire and the illuminists exalted and recommended scientific and technological work to make civilization progress. For him according to Mondin (1975), work in fact eliminates 3 great evils of humanity; bored on vice and need.

Equally, the church in her social teaching via the writings of the Fathers and Magisterium, instructs that, should one have a stranger, who should stay with him long, he should secure a work for him and let him earn his living. This means that one should be allowed to exercise his responsibility, put in Heideggerian Language, we should leap-ahead and not leap-in for one (Heidegger, 1962). 


\section{Modern Era}

With the position of John Calvin in the middle epoch that God should no more be seen as an absolute truth to be contemplated at leisure, but rather as an architect to be imitated, work became cultural. Nature was desacralized and was then seen as something to be dominated and conquered. The earth exists for man, as such, the onus lies on him to transform it and make it habitable. Man therefore became a worker, a producer. Those who do not work are either seen as anomalous or unable to work. The young are unable to work. The old have worked and retired for age. The unemployed are so because of temporal economic instability. The Hippies are voluntary drop-outs and have no positive regard in the society. Man exploits and constrains every possible mean to reveal all the mysteries of nature. In such a way, man "little by little rebels against the destiny that fell upon his shoulders and wishes to escape from the fatality that from time immemorial, he was taught to believe in as invincible (De Lubac, 1950) little wonder then, why Marx (1863) categorized man as essentially a labourer.

\section{Work and Labour Distinguished}

Generally, people take both to be synonymous but Arendt (1958) distinguished between both. Obsessed with figura etymologica, she appealed to ancient and European etymologies to show that work and labour are 2 different words though we use them synonymously. The Greeks has ponein (ponein) and evrghzestai (ergezesthai), meaning work and labour respectively; Latin has laborare or facere meaning to labour and fabricate respectively. French has travailler and ouvrez meaning to labour and to work respectively. The Germans talk of arbeiten and werken referring to labour done by serfs and to work respectively. 
The distinction between working hands and laboring bodies is akin to Greek cheirotechne and craftsmen and those who like slaves and tamed animals work to supply the necessities of life.

The Greeks did not despise only labour but also craftmen. This is because such works are not done for their own sake. They are done for the provision of the necessities of life, and as such depict the materialization of man and the suffering nature of his, whereas for theirs, a noble man should engage in contemplative activity and forget material pursuit. With this, they justified slavery. This is more because men possess slaves in order to be free from the distraction of the pursuit of the things of life, hence enabling them engage in a more ennobled work-contemplation. Thus employment of slaves for them is not against nature. For the Greeks any menial work or work done with body is servitude because it is not specific to man. Men should be contemplative. The former is denoted as Homo laborans.

The modern epoch did not distinguish between man as homo laborans and homo faber. They extolled the former and only distinguished between productive and unproductive, manual and intellectual. They based their thesis on the productive and unproductive as is observable in Karl Marx (1863) so that productivity becomes the yardstick.

The most radical view in the modern idea of labour is Marx's (1863) who said that labour distinguishes man from animals. Marx and Smith despised maids and servants as unproductive and therefore parasitic. They only work to sustain their master. This means that the moderners only re-echoed what the ancient Greeks have said. What the latter call slavish work, the former identify as 
unproductive. From the above, Arendt concluded that the distinction between productive and unproductive is also that between work and labour. For her what characterizes all laboring is that its fruit is only but for a moment as it is motivated by a stronger drive namely necessity of life.

Identification of labour and work as synonymous for Arendit is a mistake of modality. For her labour implies the physic-biological activities of the human body. It means the human condition. Arendt distinguished between labour and work based on her understanding of the world of homo laborans and homo faber. The world here is different from nature and universe. It is man-made home which is constructed with the materials provided by nature. This means that these materials are not for human life. The world makes up the condition for exercising that life. For the homo laborans, the things of the earth are just provided. He mixes up with them for consumption. But the earth seen through the eye of a homo faber consists of things ready to hand for use. He creates a new world from these materials, making the world, a more habitable place. While homo laborans does not change the earth, homo faber changes it, makes it more suitable, durable, and stable. For him, the earthly materials are useless. Their values lie in the work done on them. For them, the material things of the earth are for use. Through them, better things are created and hence their values specified. They provide the durability needed by Locke to posit his private property, value needed by Smith for market exchange and the productivity needed by Marx to show the taste of human nature. The proper use and reconstruction of these natural things, make them more durable. It does not cause them to disappear as in the case of homo laborans where the consumption of these things, makes them vanish. 
Arendt's definition could then be said to be based on crude and uncivilized man, the homo erectus, Australocanpithecus and Pithecanthropus erectus, who was used to roaming about eating whatever he saw. He is the homo laborans. The homo faber could be said to be techne-man. A civilized and civilizing man, who can transform nature, make the world a home and habitable. For her then, work becomes an activity which corresponds to the unnaturalness of human existence. Man unlike animals that work only to eat (laborans) man changes things for better (faber). In the modern epoch, and in this paper however, we use work and labour synonymously.

\section{Nature of Work}

Like language, work is a means of communication. Work is natural to man and belongs to man as such. Animals do not work. They only act instinctively. Man goes beyond the instinct and seeks selfrealisation which work offers. In the words of Pope John Paul II (1981, n.1), "work is one of the characteristics that distinguish man from the rest of creatures, whose activity for sustaining their lives cannot be called work. Only man is capable of work, and only man works, at the same time, by work occupying his existence on earth". So that for some people like Marx (1863), work is the essence of man. Equally for struhl Rothenberg (1975), "among the activities most peculiar to humans, work probably defines man with the greatest certainty" (p.273). Taking bearing from Arendt's distinction between work and labour, those of animals are laborans while man's is faber.

Some religions see work as something ordained by God. E.g is Christianity. God condemned man to eat only out of the sweat of his brow. Moreover, man is imago Dei. As such, he should work in 
order to participate in the creative act of God. Thus there had been too many definitions of work,

It is defined as an activity which enables man proposes a human milieu and transcends natural givenness in humanizing nature.

Work is the application of both the bodily and spiritual powers of man to actualize an intended goal that can be reached or produced. Here prayer becomes true work. This definition takes note of the composite nature of man.

Composta Dario (1988) has a similar notion of work, when he wrote, "work is the occupation of human energies, be they physical and intellectual, for a proper social utility" (p. 138).

Mondin (1985) in his definition said that it is a material/spiritual activity tending to a useful result or a fatiguing activity intended to modify things through the use of the body and instruments with which man searches to satisfy his own needs. The last two definitions depict work as an interaction with nature. It is a transformation of nature. It is not any kind of transformation but an intelligent one. Comte (1875) was of this view. He said it is the useful modification of exterior milieu operated by man. The human sense of work is utility. Any work done by one without useful result is no work. E.g is the myth of Sisyphus where this man makes tireless and fruitless effort to roll a big stone up a high mountain.

According to John Paul II, "man is born to work, as well as called to it. Work is for man and it is a lifelong activity which man must pursue". Human work transforms and blends new nature to man's 
likening and wishes unlike animals which is static without any development E.g. a bird must always make nest. It does not develop in that. It is only in metaphorical sense that animals could be said to work as they are operated by man. Man in his work makes present at hand, objects, ready-to-hand. He makes raw materials become useful. Thus for Marx (1863), work ceases things and raise them from death. Example the tar used to tar roads is bitumen which is a by-product of oil.

\section{Elements of Work}

Man is the worker and he works with and on something. For there to be work, two elements are indispensable. The worker and the worked or that with which he works. Where the former is the subjective the latter objective.

\section{Objective}

Work is a transitive activity. i.e. it begins in man and goes towards an external object. Work, according to John Paul II is objective when it "finds expression in different stages of culture and civilization. It goes from stage to stage. Man first takes the sea and land creatures for domestication and food. He goes further to cultivate the earth and transforms its products and adapts them for use. He goes further to the industrial stage where he employs machineries. So that as Marx (1863) noted, he only "has the unique capacity of not only using but also creating instruments to provide for his basic needs." The objective element therefore refers to activities of man done in ever changing modality, with the intention of subduing the earth. It includes all the modern techniques and machineries man uses to achieve such purpose. All the technologies as well as the products of man's brain that facilitate man's work are included in this element. They are 
generally called technology. They find expression in all human epoch. They are only ancillaries and not aptitudes for work.

As such they should be for man, not man for them. Man should be their master and not their slave. If the later ever sets in, man's pride in work goes into oblivion. What Heidegger says then crops in. This means that technology is double edged sword. It can help or kill pending on the manipulation.

The hand is a natural living instrument. Thus we often talk of the labour of our hands. Aquinas also regarded it as the most essential of all the external senses. Moreover, the tools have direct or indirect connection with the hand. They either ape its structure or depend on it for their manipulability. The hand grasps, strikes and divides. Thus the activity of the instruments as the mediator between man and work and a helper to man is recognizable in all the ages of man. Ranging from the epoch of the Neanderthal man to the stone-sharpening age heightening to a larger degree in this technological era. Instruments also modify working condition. Milton Friedman (1962) was then right to say that tool serve not to suppress man's part in production.

More so, man's ability to use and fabricate tools intelligibly marks man's crossing of the threshold between the instinct and intelligence. This is why for Bergson, intelligence is the ability to fabricate tools. So that a homo sapiens, is at first a homo faber. Tool is a sign of intelligence because it is a means. Hammer is not consumable. Its meaning therefore is manifested in its in order to. This means that tools are signs of human intelligence which works indirectly to transform nature. Thus while man is capable of representing nature, animals are only in nature. Thus Marx (1863) 
said that What distinguishes a most unskilled architect and a most clever being is that the architect carries first the house in his head. Similarly, Buber (1945) was right when he said that man's ability to discover, construct and use tools marks his emergence over animals and above all has the idea of better ones in his head.

\section{Subjective Dimension}

Work is also an immanent activity. Hence the subjective element in work. It refers to man as a person. Work is done by man. Since man is a rational being, a being with intelligence having, will, ability to choose and also a worker, then these internal attitudes of his are bound to come into his work. Such attitudes are - I.Q, temperament, character etc. As a person with free will of self decision, he is the subject of work. He originates, controls, determines and regulates the work to its end. As these internal subjective attitudes influence man's work, so they are influenced by work. Theirs is a kind of addition to their perfection. Thus, through such, he becomes truly human. Thus for Mounier (1989), all work worth to make a man as well as a thing. Similarly for Fischer Ernest (1973) maintains that by this acting on the external world and changing it, he at the same time changes his own nature. The dignity of work then comes in here, since man is solely involved. Work should be for man and not the reverse.

It is this subjective element that gives work its ethical nature because according to the Pope, it is linked to the fact that he who does it is a person, a self conscious and free subject, that is to say one who reflects upon himself. Work in the subjective sense remains the same but in the objective it changes with time. 
There are three main spheres in this subjective element- personal, familial and natural.

\section{Work as a Dimension of Human Existence}

In the words of Francis Cardinal Arinze, "Nobody was called a worker because everybody was a worker" (The Encyclical Laborem Exercens in African Context). If Arinze's view is correct, then, work becomes a fundamental dimension of human existence. The fact is made evident in the patristic and scholastic writings and amplified by Pope Leo XIII's Rerum Novarum of May 1891. Pope John Paul II (1981) writing on it said, that the church finds already in the first pages of the book of Genesis the source of its conviction that work constitutes a fundamental dimension of human existence on earth. Different and myriad disciplines that study man - Paleontology, Anthropology, Sociology, Psychology bear witness to this. It is also validated by the Judaeo-Christian tradition as seen in the book of Genesis 1:28.

Man is also expected to participate in the creative activity of God and by so doing, prolongs the creative act. The Pope expressed this in his Laborem Exercens. Man is the image of God partly, through the mandate received from the creator, to subdue and to dominate the earth. In carrying out this mandate, every human being reflects the very action of the creator of the universe (John Paul II, 1981).

Marx (1863) also in his study of man in the concrete situation saw him as an essentially working animal. An act specific to him and distinguishes him from other animals as do thoughts, wills, words and freedom. 
Mondin (1985) alluding to the above adds that just as we cannot identify man merely as a willing animal, or a playing or religious animal - so we can't just say he is only and solely a working animal "homo faber, is the man himself, in one of his essential expressions, on a level with homo sapiens, homo liber, homo volens, homo ludens and homo religiosus. But just as we have not identified man with the dimensions of willing, thinking and speaking, so we cannot identify him also with the dimension of doing. Because work is dimensions of human existence, we shall consider it in its many dimensions - natural, personal, social and metaphysical.

\section{Natural Dimension}

If man continues to live, he must always eat. As long as he remains rational too, decency demands that he must clothe himself and live under a shelter for protection against natural forces like rain and artificial ones like robbers. To provide these primary needs, he must work to transform what is already provided in raw form in nature, to suit him. Man constructs tools which lighten his toil and help him to produce more than meets his daily needs. "Working" produces "works". He does not merely catch dinner to be eaten but constructs barns to store surplus food. He is no longer content with shelter for his head but needs more worthy building in which to worship, hold assemblies, to defend himself against enemies who want his wealth. He does not merely repeat to tales around the fire, he makes paper and records works of literature. Through work, life becomes less ephemeral and more perennial. The signals turn into cars and telephones. This is quite unlike in animals; whose needs are readily supplied by nature. Man must therefore be a Prometheus to adapt to his nature. In doing this, he creates a second nature which is culture. A $2^{\text {nd }}$ nature that is unnatural, 
unique and suitable for him alone, for sustenance of life. Culture is therefore the $2^{\text {nd }}$ nature that is human. One created by him in which only he can live. And the unnatural culture is a product of a beingin-the-world. Unique, unnatural himself i.e. constructed in contrast with the environment exactly there, where for the animals the environment is situated, world of culture is for man that is to say the sector of culture, dominated and maintained by him in sustenance of life (Gehlen 1988).

Man therefore works because the nature is estranged to him. He changes it through his work and makes it familiar. He gives form to the indeterminate and makes natural force his true and obedient servants. From the famous formula of Descartes work makes us master and possessors of nature. Man needs to actualize a nature that is human. This he does through his artifacts and work. Thus for Hegel (1820), in working man reveals himself. By working man projects in advance what he is lacking now. Through it he satisfies his interests and desires. This means that he adapts the materials to suit him. Thus work is nature penetrated by subject subjectivity. Jean Lacroix (1966) on this wrote that the vital activity of animal is not work, the contemplation of pure spirit is not work. Work is always the spirit penetrating with difficulty into matter and spiritualizing it. Work fashions a new nature. Through it that which is pure and undivided but divisible assumes a variety. This is the creative aspect of work. This is why Locke saw it as conferring ownership on the individual because in working, one mixes his nature with labour. This is why for some, work is an externalization of the self. This last point leads into seeing the dialectics of alienative and re-intergration and humanization in work. Marx saw man as animal with needs - the needs to eat, shelter and cloth. To supply these, he must work. In working too, 
he does so consciously to make something human than animalistics. This means that in working, man humanizes and naturalizes himself.

Taking from the physiological perspective, man's nature supports work. His external senses - vision, auditory system, manipulability of his hands, his erect position, brain, central and peripheral nervous systems, all support the work he does. This is why David Meakin (1977) said in his man and work that work is a depth part of us which depicts not our relation to, but also our possession of consciousness which is born out of confrontation with nature. A critical look at all proffered so far reveals that work involves alienation and re-integration of man. The former because of the physical and mental stress involved in trying to transform the more or less dormant, passive and dogged nature. Re-integration of man which is the joy that follows the eventual success.

\section{Personal Dimension}

Man does his work with the help of some parts of his body. The latter, since it is material alone, should be inactive without the spiritual aspect of man. This means that both aspects of man are involved in man's work. i.e the whole person is involved. Therefore it has tremendous personal dimension. Work comes from and for man. So that as noted by Vatican II as human activity proceeds from man, so is it ordered towards man. This means that it is work for man and not man for work.

The personal dimension of work is also seen in its process and end. Many traditions see it as punishment. Something reserved for animals and slaves. A kind of alienation. it is also a remedy of alienation in the end. This is the position of Jean Lacroix (1966). 
For Christians too, work is not punishment. Thus St. Paul in one of his letters advises Christians to go on working to earn their living (cf. Eph 4:28). For Hegel too, work liberates as is seen in his dialectics of the master and the slave.

Man by engaging in work dispenses energy which is under the control of the body and intelligence. Because work needs the involvement of the whole man, man concentrates. His being becomes organized. He is no more scattered. He realizes himself having forgotten his being through his whole engagement in work. Thus through work, one liberates from the shackles of earthly distractions. He also recreates and perfects himself. So that as noted by Elliot (1961), a man's work does not satisfy his material needs alone. In very deep sense, it gives him a measure of his sanity. Work is therefore man's mirror because it is nature controlled by reason and transformed. So that a good work attracts praises for the doer - the heavens proclaim the greatness of God. Work enables man. This why modern technology, though should help man, must not be allowed to become means of subjugation and human programming. For Evan Illich (1971), this constitutes the error of modern industrialism. With Heidegger (1962) then we say that, Man must say 'yes' to technical utensils, but he must say 'no' to their pretences of monopolizing all the meanings of being.

Through work then, man puts value in things. For oneself, liberation, for others, recognition; for production in itself; it then becomes a monumentalization and immortalization of the self.

\section{Metaphysical Dimension}

The metaphysical is not severed from the personal. The spiritual aspects of man, will, reason etc involved in work show the spiritual 
aspect involved. Metaphysical is that beyond matter. The spiritual is beyond matter and therefore metaphysical.

The metaphysical dimension seeks to demonstrate that man is not pure spirit, whose activity will not meet any obstacle or just more matter which cannot in any way transcend nature. Thus Jean Lacroix (1966) noted that the vital activity of an animal is not work. The contemplation of pure spirit is not work. Work is always the spirit penetrating with difficulty into matter and spiritualizing it. Work therefore shows the condition of man as incarnate spirit. Equally from the religious point of view, man is an incarnate spirit. This is because, he is created in God's image and God is a spirit. Since man who has matter is created in the image of the matterless God, it means that some form of matterlessness must be in him in order to have the divine image. Since we see only the material part of him that matterless part, must be in the matter. Man therefore is an imago Dei (John Paul II, 1981).

\section{Moral Dimension}

This is inseparable from the metaphysical dimension. Just like other activities of man, human work can also be good or bad according to the good or evil end for which the person works. E.g. production of medicine is not automatically good work. Its goodness or badness depends on whether it is produced to cure or poison someone. In the words of Pope Leo XIII (1891), the ethical value of work "without indefinite statements and directly speaking, remains bound to the fact that he who fulfills the task is a person, a cognizant and free subject that is a subject who decides for himself. 
Work is morality in act because morality according to Mondin (1985) is only an incarnation of value in reality. Work not only humanizes the universe, it also perfects man. Thus for Mounier (1989), all work, worth to make a man as well as a thing, work is the best exorcism for egoism. Though man works subjectively for utility, there is also the objective end which is realized in the product of the work because working is to quit oneself, to externalize oneself. It helps man regain some equilibrium. This is why psychiatrists use ergo therapy on some on their patients showing the therapeutical value of work.

Work gives order and balance to existence. An idler or a loafer has time disjuncted and discontinuous. It is heterogeneous and runs like capricious rhythm of passions. The worker whose time is regulated is more organized, stable and experience regular rhythm of things. Comte gave a good formular for the psychologists, "regulate the inside through (on) the outside". Regulation here does not mean programmation but as free act. Thus an adage has it that idle -hand, foolish heart.

Another aspect of the moral dimension of work is the condition of work. This was pointed out by Mondin (1985). Man is capable of both noblest and basest action. Thus for work to be ethical and perfective to the performer, it is necessary for it to be firstly morally healthy. This is founded on the fact that man is a free subject who decides for himself.

In concluding this section, we document with John Paul II (1981) that though work is an arduous good, it needs be done, not just for the joy of the fruit but that through it man solves his needs and that 
of others and also humanizes nature. Such work must, however, recognize the dignity and perfection of the human person.

\section{Social Dimension of Work}

For struhl and Rothenberg (1975), work is an activity that produces something of value for other people. This means that although work emanates from a human person, it is nevertheless social. Almost every person testify to this. Freud saw love and work as the foundation of the society; Marx (1863) said it is an activity done in association with others in which man reflects himself as a special being. John Paul II said that the building of the society is its primary task. Vatican II Gaudium at Spes is of similar view. It says, "By his work, man ordinarily provides for himself and his family, associates with others and his brothers and renders them service (G.S no 67).

Work is not only a personal activity. It brings one into the interior of social organism in which all the component parts are in solidarity. Mondin (1985) expresses this more apophantically when he said that work has a social value because the work one does not only perfects or damages the door, but extends to other members of his kit and kin. This is very true especially for work as a transient action. This social dimension of work can be seen from six different perspectives which can be merged into three or more greater wholes.

From the viewpoint of actual working process

Result of work

Division and organization of labour

Realization of collective interests

Social right

Economic and political organization of society 
The process of work proves work to be social activity. Though some productions go without help of others, most is conjoined effort of many people. Working then becomes a unifying activity. Camaraderie is encouraged through work. Work therefore becomes a communicative endeavour. This is why Rousseau said that the first language is a product of work as people shouted and Nyerere's view of Ujamaa is also based on this view of work as a social activity. Work then needs complementariety, to make up for the lacks. Hence the idea of the division of labour in which everyone offers his own quota for the realization of a project.

This is akin to the idea of division of labour and human solidarity discoverable in work. Thus John Paul II in his address to Nigerian workers on the $16^{\text {th }}$ February, 1992, held that work is a way of helping others. One's work affects the other and so they build up the society, so that one who works conscientiously can claim to be contributing immensely to the society and towards a better world. Work therefore, is an act of solidarity and this is observable in the mutual help we give to one another. Solidarity may be horizontal or vertical. The former is the mutual help workers render to each other. Leon Bourgeois noticed this when he said that men cannot accomplish the simply ordinary actions like lighting a lamp, drinking a cup of water without making use of the others contributions. So that one's work is only a remuneration one gives for making use of others work. This means that duty is infinitive debt. This is solidarity seen horizontally.

Vertical enables one benefit from the sweat of his fore-fathers, and consequently binding him with stronger fetters to work for his posterity. This is why Comte said the inventor of the plough 
labours invisibly at the side of the labourer and humanity is made up of more of the dead than living.

A family if any, without means of sustenance can last only but a moment. There is no other means of income for sustaining the family except through work. Thus for John Paul II as for Freud, work makes up the foundation for the family. The family is a miniature nation. It is the nucleus of the nation. Work also influences the education in the family. This is because; one works to become human and the reason for education is to make one human. A combination of the above 2 views lays bare the 2 aspects of work - formation of the family and actualization of the purpose of the family. The family is a community made possible by work and the first school of work made possible within the home for every person.

Since the nation develops out of the family and the latter through work, it means also that the mainstay of the nation is also geared to work. The nation is then a concatenation of a broken or unbroken line of historical and social incarnation of work of all epochs. A nation cannot be without productive forces and economic base and the latter are only sequent to work. if these are true, then men form society through work. Thus by identifying himself with his community and working for the common good together with his compatriots and through such dominating and conquering nature, a second or cultural world is created for better human living and subsistence. It is only through work that the human person is both phenomenologically and socially realized, starting from the first emergence of society in the unity in the family when people work for common good, till its graduation into state and nation. This is because the more living organisms unite into a social whole, the 
more progress is affected and this is via work. The scope created by work may be advancing from crude to technological scope. Pope John Paul II (1981) was of like opinion when while supporting Pius IX (1931) noted that work has as its characteristic that first of all, it unites men and in this consists its social force to construct a community. Definitely in this community those who work must in some way unite themselves as much as do those who dispose of the means of production who are its proprietors.

\section{Civilization Expression and Fruit of Work}

Though work is not the sole or ultimate end of existence, the development of man both psychologically and technologically is because of his work. Wherever the urge for work has remained stagnant and primitive, the development has remained considerably low. John Paul II (1981) holds that, it is by his work that he must help raise ever higher the moral and cultural standards of the society in which he shares his life with brothers and by work he raises the standard of civilization.

Metaphysically, if one refuses to work, he has also refused using the essential and personal forces. This is because work needs both the physical and spiritual aspect of the subject. Civilization is the terrestrial end of man because it takes up and expresses the becoming and expansion of the spiritual energy which God have given man. Also we strive to go to heaven because it is a place of eternal joy. Similarly, no one prefers living in a crude and primitive place. Civilization makes a place less crude and primitive and civilization come only through work. Therefore civilization which makes the temporal world habitable and happy to be lived in should be the terrestrial end of man. 
Civilization is only a gradual external unfolding in time and history of the spiritual being. It is intensification of all that is man and the interior growth of the spirit in itself, development of action and power to triumph over fear and needs. But all these through work.

\section{From the Point of View of Rights and Economic and Political Organisation of the Society}

The social and political order has work as an auxiliary to its foundation. Thus Plato in his Republic organizes his government according to the work done by each group. Equally, the highly intricate and sophisticated and developed society, enjoys higher standard of living than the under. This would have been impossible if not via work. In order to live, one is obliged to work. If this is correct, then work becomes a means of livelihood. This is done by conferring right of ownership to the worker especially of the dividend and remuneration accruing from the work. This is why the U.N.O charter of 1948 holds that everyone has right to just salaries. Writing on work as a duty, John Paul II said that man works because God commanded it and because through it he maintains and develops his being and more for his family, society and posterity as he inherited from anterior. Going further, he said that this obligation to work, guarantees the worker, a right to wage. This presupposes relationship, between workers and employers. Such relationship must be judiciously reciprocative i.e. the worker works conscientiously while the employer gives him his due. This is why in his address to U.N.O on October $2^{\text {nd }}, 1979$, he argued against exploitation and exaggerated capitalism on the ground that economic strength of a community should be measured on humanitarian basis and not on hegemony or imperialism. This means that man and not the income, should be the centre of consideration. Laws should be made to favour man and the 
condition of work must be for his good. Every political and economic system must be for man's good, assuring him at least, of the basic necessities of life.

These raised a lot of issues on the problem of employment and unemployment, labour and capital etc. capitalizing on what is generally called the antinomy of work in the concrete historical reality. Such antinomies include external values in times freedom in necessity, moral transcendence in contingency of becoming etc It was to tackle some of these problems that various economic systems have come up.

1) Economic liberalism preaching freedom of man in all things. Individualistic self-interest leading to capitalism.

Today it has split into two.

2) Libertarians who are conservatives of hard capitalisminspired by Adam Smith and Locke, defended by Hayek; represented by conservative rightist like-IMF, Conservative party in Britain.

3) Mitigated capitalism- initially defended by J.S. Mill; defended in Economics by Heynes and today John Rawl, democrats in U.S.A and labour party in Britain. They uphold State interventionism.

\section{Conclusion}

Work is part and parcel of man. By nature man lives up to his potentials through work. By means of his work, he betters the society for his own good. Thinkers have proven that man cannot but work. Nature has made it so from the point of creation. The opposite is strange to human nature. Often people seem to interpret work only from its wearing perspective. This paper has 
demonstrated from the thoughts of many scholars, secular and religious that man is not just a homo faber, by working he perfects himself. In Gen. 1,26-28 God created man in His own image. When the bible talks of image, it is not image in the sense of pictorial representation. Until the creation of man, God posits Himself as a working God. Thus creating man in His image means making man a working man just as He is Himself a working God. It is in this backdrop that Paul out rightly condemns every form of laziness. He says, ei; tij ouv qe, lei evrga, zesqai mhde. evsqie, tw (...if anyone wishes not to work, let him not eat 1 Thes 3,10 ). Work fulfils man's destiny. It informs and perfects the whole man. Horizontally it betters man's life on earth. Vertically it propels man to his eternal destiny, his fulfillment in Christ.

\section{Dominic Obielosi \& Stanley Mgbemena}

Nnamdi Azikiwe University, Awka dobielosi@yahoo.com

\section{References}

Mondin, B. (1985). Philosophical Anthropology: An Impossible Project? India: Theological Publications.

Heidegger, M. (1962). Being and Time. J. Macquarrie and E. Robinson trans. New York: Harper and Row Publishers.

De Lubac, H. (1950). The Drama of Atheist Humanism. M. Sebanc trans. London: Sheed and Ward Publishers.

Arendt, H. (1958). The Human Condition. Chicago: University of Chicago Press. 
Marx, K. (1863): Capital: A Critique of Political Economy, F. Engels ed. Chicago: Charles H. Kerr and Company.

Struhl, K and Rothenberg, S. (1975). Ethics in Perspective. New York: Random House Inc.

Dario, C. (1988). Moral Philosophy and Social Ethics. Rome: Urbaniana University press.

Comte, A. (1875): System of Positive Polity. London: Longmans, Green and Co.

Friedman, M. (1962): Capitalism and Freedom. Chicago: University of Chicago Press.

Buber, M. (1945). "The Philosophical Anthropology of Max Scheler", in Philosophy and Phenomenological Research, vol. 6, no. 2 (Dec. 1945) pp. 307-321.

Mounier, E. (1989). Personalism. Notre Dame: University of Notre Dame Press.

Fischer, E. (1973). Marx in His Own Words. A. Bostock trans. New York: Penguin Books Ltd.

Leo XIII (1891). Rerum Novarum. Encyclical Letter on Capital and Labour, May 15, 1891.

JohnPaul II (1981). Laborem Exercens. Encyclical Letter on Human Work.

Gehlen, A. (1988). Man, His Nature and Place in the World. C. McMillan and K. Pillemer trans. New York: Columbia University Press.

Hegel, G.W.F (2000). Philosophy of Right, S.W. Dyde trans. Ontario: Batoche Book Ltd.

Lacroix, J. (1966). Panorama de la Philosophie Francaise Contemporaine. Paris : Presses Universitaires de France.

Meakin, D. (1977). Man and Work: Literature and Culture in Industrial Society. Cambridge: Cambridge University Press. 
Elliot, J. (1961). Equitable Payment: A General Theory on Work, Differential Payment, and Individual Progress. London: Heinemann Educational Books.

Illich, I (1971): Deschooling Society. New York: Harper and Row. Pius IX (1931). Quadragesimo Anno. On Reconstruction of Social Order. Encyclical Letter on the Condition of Workers. 